\title{
Mystical Experience and Global Revolution
}

\author{
By Mike Sosteric*
}

\begin{abstract}
Since Marx first declared religion to be the opiate of the masses, institutions of religion and spirituality have often been resisted by scholars. The assumption of many seems to always be that religion is either a reactionary response to difficult realities or a mere illusion, delusion, or epiphenomenon of brain/social function. This paper looks at the "authentic core" of religious institutions, religious/mystical experience, and, using biographical examples from the literature, argues that far from being a reactionary holdout of our primitive past, human spirituality is, in fact, essentially revolutionary. It is suggested that, in the context of a growing global ecological, political, and economic crises, the revolutionary authentic core of religion and spirituality has to be examined, recovered, and even embraced as part of any local or global strategy of transformation.
\end{abstract}

Keywords: Marxism, Mysticism, Mystical Experience, Sociology.

Arise, o son! Burst the bonds and be free! How long wilt thou be captive to silver and gold?

Rumi

\section{Dangerous Memories - Slavery, Mysticism, and Transformation}

The business for which GOD sends a Christian priest in a Christian nation... is to preach and practice Liberty, Equality, and Brotherhood (sic), in the fullest, deepest, widest meaning of these three great words. In so far as he does, he is a true priest, doing the LORD'S work with the LORD'S blessing upon him. In so far as he does not, he is no priest at all, but a traitor to GOD and man (Charles Kingsley quoted in Masterman 1907: 98-99).

In 1912, Troelsch, with the publication of Die Soziallehren, established a tripartite scheme for examining human spirituality known as the church-sectmysticism scheme (Garrett 1975). In this scheme, Troelsch identified three key aspects of human spirituality, these being the organized and institutionalized church experience, the less organized sect/cult experience, and the individual mystical experience. As Garrett points out, Max Weber knew about this dimension. Subsequently, however, he and all other sociologists have focused primarily on the Church and, to a lesser extent, sect divisions of Troelsch's scheme, either ignoring the mysticism component altogether or dismissing it as a bad thing, a primitive thing, an irrational thing, a declining thing, and a thing that is not worthy of attention (Featherstone and Sorrell 2007). In sociology there is this conception that there is nothing in mystical experience to warrant anything more than minimal scholarly interest. As regards mystical experience, sociology has adopted, according to (Cohn and Markides 2013), the separatist

*Associate Professor, Athabasca University, Canada. 
principles of its founding elders. These principles led the founding elders and subsequent generations of sociologists to deal with religion up to a point, focusing on the institutional parameters and beliefs, and maybe making mention of mysticism here and there, but generally failing to engage more than a cursory examination of mystical experience (Summers-Effler and Kwak 2015). Ultimately it was expected that sociology would be mysticism's executioner. As Cohn and Markides (2013: 34) note, "They claimed that, as a science, sociology would disprove the claims of religion and establish human knowledge upon purely material foundations." These "separatist aspirations" are especially prevalent in sociological luminaries who have rejected spirituality and as elite machination (Berger 1969, Marx 1978) cussed stupidity (whose discussion is "beyond the pale" of self-respecting faculty parties (Berger 1999: 4)) and implausible (Bruce 2002, Dobbelaere 2002, 1981, Berger 1969, 1968) and superstitious nonsense likely to die out as secularization tromped its way through the unfolding history of modernity. This misconception is formalized in Durkheim's secularization thesis (Durkheim 1965) which holds that religion would eventually die out as society modernized and industrialized.

As many are now aware, the secularization thesis has proven to be either wrong or at least not as straightforward as first imagined (Berger 1997). Unfortunately, that has not led sociologists to take mysticism and/or religion experience more seriously. Despite its early incorporation and theoretical integration into the "full sweep of ... historical-sociological analysis" (Garrett 1975: 207), despite Max Weber's early interest (Robertson 1975), and despite the fact that other disciplines have a long history of looking at the third dimension, i.e. mystical experience, (Chen et al. 2011, Anthony et al. 2010, Lazar and Kravetz 2005, Hood et al. 2001, Stace 1960a, James 1982, Freud 1964, 1961, Maslow 1994, 2012, Proudfoot 1985, Newberg et al. 2001), sociologists remain largely silent. Despite some early interest a long time ago, (Bourque 1969, Bourque and Back 1971, Tiryakian 1972; Truzzi 1974, Greeley 1975, Hermanns 1983), "the concept of mysticism has mainly experienced wholehearted neglect at the hands of sociological investigators..." Garrett (1975: 206) who have displayed only parochial interest in ecclesiastic institutions (Garret 1975: 220). The nest result is absolute neglect of religious experience on the part of the discipline of sociology.

Why is this? Bellah (1970: 92), in support of a more open minded inquiry, accuses sociologists of a "cognitive bias" that has led them to engage in acts of symbolic and consequential reductionism that have profoundly undermined their ability to understand religion and religious experience. This bias almost certainly exists, and there is some justification for it. Sociologists are aware of negative aspects of religion/spirituality. In the name of religion, all sorts of violence has been perpetrated (Ellens 2001). People have abused children (Dawkins 2006b), drank cool aid, gone on crusades, and even slow roasted native populations in the name of the Lord, when they needed to use them as slaves. This we cannot deny. But, religion itself is but a foil. Violent people use religion as a justification for violence, that is true. But violent people also use politics, race, and even science to justify their violence (Morena 2000, Washington 
2008). You cannot single out religion in this regard and in any case, of all the institutional and material props for violence that there are, religious experience at least doesn't seem to be the best one to use. Sure, some religions may be used in an opportunistic fashion to prop up venal economic, social, and political interests (Sharp 2016), but when you look closer you find that authentic spiritual/ religious experience isn't compatible with venal economic or political interests. There is, "something more" buried deep within the mystical spirituality and religion of this planet, something at the core, a "reality towards which religious [sic] point" (Cohn and Markides 2013: p. 36) that belies attempts at venal, even capitalist, abuse. ${ }^{1}$ This "something more" is neither bad, nor primitive, nor irrational, nor stupid, nor (it should be strongly emphasized) unworthy of scholarly attention. In fact, quite the contrary is true. Whatever it is that is there requires a closer look, right now. Recently, a United Nations Panel on Climate change issued a remarkable, doomsday report. Climate change is bad and getting worse. According to the report, there are no mitigating factors, no hope on the horizon, and not much we can do except "deal with it." Icecaps are melting and threatening coastal regions, oceans are becoming acidic and killing fish, coral reefs are dying, creatures are migrating to (and from) the poles, and the weather gets crazier every year. In the immediate future we are looking at increased injury and death as the result of violent weather, public health catastrophes as people start to migrate from uninhabitable areas, and interruptions in the food supply. Down the road (actually it is happening right now), we'll see increasingly violent conflict over land and resources and even starvation. Of course, people with money will be buffered from the worst of it, for a while. They will be able to relocate to higher ground and they will have money to purchase even the most expensive food, but poor people, esp. those in developing nations, won't fare so well. Like victims in Phuket, the poor do not have resources to build better houses, move to higher ground, or buy expensive food as supplies become short. ${ }^{2}$ In the context of expanding global social, psychological, political, economic, and ecological crises, it is this author's contention that deep within the authentically mystical core of religion is a transformative spirituality that is (at least part of) the solution to the deepening crises of our time.

\footnotetext{
${ }^{1}$ In this essay I will use the phrases mystical experience, transcendent experience, and spiritual experience to refer to the same general experiential phenomenon that I conceive of as "authentic connection" to The Fabric of Consciousness. For a definition of The Fabric of Consciousness, see Sharp M. (2006) The Book of Light: The Nature of God, the Structure of Consciousness, and the Universe Within You, St. Albert, Alberta: Lightning Path Press.

${ }^{2}$ It is noteworthy that even the über rich see the disaster coming and aren't necessarily optimistic about the future. As for example Robert Johnson of the Institute for New Economic Thinking suggests. See https://www.youtube.com/watch?v=Sriuwxwols8\#t=258
} 


\section{The Mystical Core?}

At this point I imagine that incredulity is the response of some readers. The anti-spiritual programming that many of us are exposed to is quite strong. There is nothing in mystical experience or religious experience, we are told, to warrant significant attention. Weber mentioned it, for example, but then never bothered to develop an adequate or even consistent theorization (SummersEffler and Kwak 2015). Smart people, we are told, do not give it a second go (Berger 1999: 4). If you are an academic, you cannot even talk about it and if you do, if your scholarly interest outweighs your fear of persecution, you have to engage in requisite denials. You are interested, but not involved you will say. You find something worth looking at, but quickly add you are not looking for "God." There may be something to talk about, but enlightenment is not what you seek. Like Peter in the bible story, you deny your interest and affiliation out of fear of censure and violence. And note, it is not an unreasonable fear. Rupert Sheldrake was excommunicated from science, and the editors of the esteemed journal Nature called for the burning of his books, when he presented theories outside the canonical materialism of natural science (Freeman 2005).

Given the state of the world, it is time we put aside a fear of open inquiry, so, I will say it directly. There is something in mystical experience/religious experience worth looking at. Scholars have been interested religious/mystical experience for a long time. Abraham Maslow, founder of both the Humanist and Existential schools of Psychology, spent his entire career studying them (Maslow 1943, 1959a, 1959b, 1964, 1968, 1969). R. Bucke, a Canadian medical doctor and graduate of the McGill medical school, speaks of men whose eyes have been opened, have had a new birth, and have "seen" (Bucke 2009/1929: 11). Roberts (2014: 7) says that "...mystical experiences...have been a central part of theology, philosophy, and religious practice throughout the history of religion." Stace (1960b: 14) says:

If anyone thinks that a kind of consciousness without sensations, images, or thoughts, because it is totally unimaginable and inconceivable to most of us, cannot exist, surely he is being very stupid. He supposes that the possibilities of this vast universe are confined to what can be imagined and understood by the brains of average human insects that crawl on a minute speck of dust floating in illimitable space.

This is not delusion. When one digs deep enough, one finds that many significant cultural and scientific figures (Wilber 2001) have had mystical experiences. Parmar (2002) notes that both The Divine Comedy and Paradise Lost are based on the spiritual/mystical experiences of the authors. William Blake, respected English illustrator and poet, reveals his own mysticism in letters to his friend Thomas Butts (Blake 1906d, 1906c, 1906a, 1906b, 1906e). Walt Whitman did not hide his mystical experiences (Whitman 2007). Even socialists, as it turns out, have their unrepentant mystics (Sime 1916) and their mystical socialist texts (Carpenter 1896). Indeed, Edward Carpenter, who was 
an important early figure in the emergence of socialism (Rowbotham 2008, 1980) was a poet, writer, and mystic. He was a left wing pacifist, an LGBT $^{3}$ activist way before his time, and it must be strongly emphasized, the person who coined the term cosmic consciousness! Carpenter was not a stupid man or a shill of the ruling classes by any means, yet he was a mystic and he did write about God, consciousness, creation, and the capitalist social disease (Carpenter 1921, 1896, 1889).

\section{What is Mystical Experience?}

If the reader does not dismiss outright the validity of mystical experience as an object of sociological inquiry, then the next question becomes "what is mystical experience"? As this author points out (Sosteric 2017b), there are two ways to conceptualize mystical experience. One can view it as scientists view it, i.e. as an objective observer looking "at" the mystical experience itself; or, one can view it as the mystics themselves view it, as a subjective experience. Scientists who have looked "at" mystical experiences have, for the most part, seen mystical experience as a secondary manifestation of something unrelated to religious realities. That is, mystical experience is either a psychological function (sometimes seen as pathology and sometimes seen as adaptive), evolutionary imperative, neurological epiphenomenon, or reflection of human social structures.

The scientists' view is quite different than the mystics view. Mystics themselves view their experience simply as union with "God" (Inge 2005: 8). That seems simple enough to grasp. Mystical experience is a union with God. Of course, saying this makes people uncomfortable, partly because some scholars, though not all (Ecklund 2012, Ecklund and Long 2011), reject the notion of God or Consciousness as separate from physical matter, and partly because even if you do not reject the notion outright, the term "God" carries so much religious, spiritual, and scientific baggage as to be an entirely useless term. I could say that "mystical experience is union with God," and I would have absolutely no idea what your idea of God is, or what sorts of Dawkining "issues" (Dawkins 2006a) you might have with the term. In order to avoid the semantic confusion, baggage, and negative connotations, over the decades, scholars have used different terms to describe the thing we connect to. Underhill uses the term Reality with a capital "R" or the "Absolute" to describe the "thing" that mystics connect to (Underhill 2002). Bucke (2009/1929) and Carpenter (1921) use the term Cosmic Consciousness. Happold (1963) says Ultimate Reality. Alighieri (1915): Canto 33, line 91 says Universal Form, Blake (1977) describes it as Imaginative Vision. Einstein calls it the "Old One" (Martin and Ott 2013). Sexist mystics call it "Him" (Vergote 2003: 81), or even the Holy Spirit, Inge (2005: 8) calls it the Holy Spirit. I, probably in agreement with what an ancient Rishi might say, would say we say we're making a Connection to Consciousness (Sharp 2010).

Using a term different than "God" may ease resistance, but throwing a

${ }^{3}$ Lesbian, gay, bisexual, and transgender. 
bunch of terms into the hat to try and assuage scholarly indigestion only creates Babylonian confusion. Rather than contribute to the confusion, this paper simply accepts the mystic's description at face value: a mystical experience is a connection with God. If the reader is uncomfortable with this simple, but ecologically valid, description, then at this stage simply empty the term of meaning. At this stage of the game we can say nothing about the nature, scope, purpose, or even ontological status of God; we just know that when mystics have an experience, this is what they say they connect to. This is our starting point and if we are going to develop an adequate understanding of mystical experience we cannot be turned from this point.

\section{What Happens When You Have a Mystical Experience?}

Now if, for the moment, we take for granted that mystical experience is the common core of authentic religion, and if we take for granted that a mystical experience is connection with a thing that we might call God, we raise many questions (Sosteric 2016). What is God? How is "connection" (whatever that might be) facilitated? What happens when we connect? While all the above questions are valid and worthy of attention, in this paper, we will put aside these many issues and instead focus specifically on what happens following a mystical experience. As it turns out, many things happen to an individual following a mystical experience. These things range anywhere from positive mental and emotional changes (Hood Jr et al. 2009), to new outlooks and renewed optimism, to spiritual emergency (Grof and Grof 1989), and sometimes psychosis! It is a mixed bag to be sure, but it is mostly positive. Most famously, Maslow's research on peak experiences indicated that religious experiences are an indicator of psychological health (Maslow 1964, 1969). Interestingly, links between spirituality and mental and physical health have been supported by a wealth of research (Hood Jr et al. 2009). Ellis, who was originally a huge critic of mystical experience (Ellis 1988), has more recently moderated his claims and admitted the positive and potentially helpful nature of said mystical experience (Ellis 2000).

As interesting as the positive psychological sequels of mystical experience might be, far more interesting, at least from a sociological perspective, is the potentially personally, socially, and even politically transformative nature of mystical experience. When an individual has a mystical experience, when an individual "makes a connection," they are often and notably transformed. As Happold (1963: 39) notes

Such experiences, when they happen to a man [sic], revolutionize his outlook, often change his life. He may carry on with his normal occupation as before. To his friends and acquaintances, he may seem to be the same as he always was. But in himself, he is changed. He feels that he has received a pure, direct vision of truth. Nothing can be the same again. 
Note that these transformations are not impotent internal experiences necessarily kept to oneself. The transformation can be a little transformation, as for example the minor peak experiences researched by Abraham Maslow (Maslow 1994, 1971), or they can be fundamental political, intellectual, and moral changes affecting a "broad range of personal emotion, cognition, and behaviour," (p. 453) what Miller (2004) describes as "Quantum Changes." Indeed, Bucke thought that moral changes, what he called moral elevation, were a fundamental and distinctive characteristic of authentic mystical experience. Although subsequent researchers have ignored this key feature of mystical experience, likely for conservative political reasons (Jantzen 1995), Bucke (2009/1929) noted it in the lives of many famous mystics, like Meister Eckhart, Jacob Bhoeme, and others. For Bucke, this moral elevation is a putting aside of the venal interests of greed, graft, power, and money, and a turn toward the collective good of humanity. Bucke is succinct about what he means by all this when he interprets the life experience of Jesus Christ.

Suddenly, instantaneously, the change came, and this young man felt and knew within himself the seemingly illimitable spiritual force through the exercise of which almost anything might be accomplished. How was it to be used? To gain what end? Power? Wealth? Fame? Jesus quickly decided, as these men all decide, that the power must be used for the benefit of the race. Why should he, why should they all, decide in this sense? Because the moral elevation, which is a part of Cosmic Consciousness, will not permit any other decision (Bucke 2009/1929: 101).

It does appear to be true. If you are Christian, you will know that Jesus Christ was not a fan of money, greed, or the economy. He threw the money lenders (i.e. bankers) out of the temple and told rich people that it was easier to get a camel through the eye of a needle than get them into the Kingdom of God. ${ }^{4} \mathrm{He}$ was, as I argue elsewhere, an anti-authoritarian, political revolutionary (Sosteric, 2017a). Similarly Gautama Buddha, in The Great Decease, rejected materialism, greed, and profit, as "lesser things" (Müller 1881) and ended up advising his followers to seek the light. More recently Mother Teresa's mystical connections led to transformative social movements (Summers-Effler and Kwak 2015). Miller (2004: 457-458) provides an enlightening overview of the quantum change in values and priorities that sometimes come from mystical experience.

Another major change that quantum changers reported was in their values and priorities. Looking back at their core values before their experience, men reported that their top priorities had been wealth, adventure, achievement, pleasure, and being respected; women said that family, independence, career, fitting in, and attractiveness had been most important. Both reported an abrupt and enduring shift in their most central values. After their quantum-change experience, men ranked spirituality, personal peace, family, God's will, and honesty most highly; women valued growth, self-esteem, spirituality,

\footnotetext{
${ }^{4}$ See Mathew 19: 23-24.
} 
happiness, and generosity. They were no longer possessed by their possessions. Often, characteristics that had been valued least became most important, and those that had ranked as highest priorities fell to the bottom. Spirituality, though not necessarily religion, became central for many. Relationships were changed, too. Quantum changers often seemed to lose their tolerance for superficial relationships. They wanted fewer and closer friendships. Some experienced sudden healing of and release from enmeshment or abuse they had experienced in childhood. Others found the courage to leave abusive relationships. For some, family and intimate relationships became more meaningful and peaceful. (pp. 457-8)

As noted, Miller calls the change "quantum change." As a critical sociologist, I would call this a mystical "turn to the left" and I would state, unequivocally, that it is quite fascinating. Could it really be true? Could mystical experience lead to the emergence of humanist, even socialist values? Certainly, you find many examples in the biographical literature of the "turn to the left" that follows mystical experience. When Edward Carpenter (a famous socialist) had his mystical experience, he promptly threw off his academic shackles and went to work the land. He was a Cambridge Scholar of first class degree, but he tossed it all and became a tireless advocate and supporter of progressive politics. His transformation was dramatic.

He was involved in some of the earliest socialist groups, actively supporting workers in struggle. He was a leading proponent of utopian communes, a pioneer of the environmental movement. He was also something of a newager, into paganism and Eastern transcendentalism. He campaigned for women's equality and produced groundbreaking material on homosexuality (Anon 2009).

Other examples may be found that are even more striking and dramatic. Consider the story of Bartolome de las Casas. Bartolome de las Casas was a Spanish noble that lived during the sixteenth century. Like all Spanish nobles of that time, he was directly involved in colonization. In particular, he was involved in the colonization of Hispaniola and Cuba. Fiske (1902) provides a scathing indictment of Spanish colonizers with a particularly vitriolic condemnation of Las Casas whom he called the worst of the slave drivers. It seemed there were no boundaries around the horrors he would commit. As Fiske notes of the repressive practices of the colonizers:

Indians were slaughtered by the hundreds, burned alive, impaled on sharp stakes, torn to pieces by blood-hounds. In retaliation for the murder of a Spaniard, it was thought proper to call up fifty or sixty Indians and chop off their hands. Little children were flung into the water to drown with less concern than if they had been puppies. In the mingling of sacred ideas with the sheerest devilry, there was a grotesqueness fit for the pencil of Dore. Once, "in honor and reverence of Christ and his twelve Apostles," they 
hanged thirteen Indians in a row at such a height that their toes could just touch the ground and then pricked them to death with their sword-points, taking care not to kill them quickly. At another time, when some old reprobate was broiling half a dozen Hideout Indians in a kind of cradle suspended over a slow fire, their shrieks awoke the Spanish captain who, in a neighboring hut, was taking his afternoon nap and he called out testily to the man to despatch those wretches at once and stop their noise. But this demon, determined not to be baulked of his enjoyment, only gagged the poor creatures (Fiske 1902: 265-266).

Las Casas, like all other nobility of the time, was part of this horror; but then, something remarkable happened. One day while in Cuba, Las Casas read from Ecclesiasticus (Sira 34: 21-23) the following words:

The Most High is not pleased with the offerings of the wicked: neither is he pacified for $\sin$ by the multitude of sacrifices. The bread of the needy is their life; he that defraudeth him thereof is a man of blood. He that taketh away his neighbors' living slayeth him; and he that defraudeth the laborer of his hire is a shedder of blood.

Upon reading these words, Las Casas has a classic mystical experience which was followed by an instantaneous transformation in his view of slavery and a subsequent shift in his political work. Fiske provides an account of what happened:

As he read these words, a light from heaven seemed to shine upon Las Casas. The scales fell from his eyes. He saw that the system of slavery was wrong in principle. The question whether you treated your slaves harshly or kindly did not go to the root of the matter. As soon as you took from the laborer his wages, the deadly sin was committed; the monstrous evil was inaugurated. There must be a stop put to this, said Las Casas. We have started wrong. Here, are vast countries which the Holy Church has given to the Spaniards in trust, that the heathen may be civilized and brought into the fold of Christ; and we have begun by making Hispaniola a hell. This thing must not be suffered to grow with the growth of Spanish conquest. There was but one remedy. The axe must be put to the root of the tree. Slavery must be abolished (Fiske 1902: 273-274).

Following his mystical revelations, Las Casas gave up his slaves, went into the pulpit, and preached against the practice. He also sold his worldly goods and went to visit the King of Spain, The Bishop Fonesca, and others. He became politically active and was a key figure and major influence (Fiske 1902) not only in advocating against slavery, but in advocating for the idea that the slaves were human and had souls (Cels 2014). Eventually, he went on to write a rather disturbing book on Spanish treatment of slaves where he provides a first-hand account of a horrific genocide that left Hispaniola a ruinous and 
desolate waste (Casas 1552). ${ }^{5}$ This is a far cry from the colonizing demon that initially stepped foot on Cuban soil!

\section{A Turn to the Left and a Call to Action}

At this point, the obvious and pressing question is, how can an experience of a "light from heaven" yield such a powerful and transformative outcome? The question is not so easy to answer, especially if you are a sociologist who won't even look at the phenomenon of mystical experience. But even those who look, struggle. Those that have commented have generally reduced these experiences to psychological or more recently neurological or epiphenomenon (Sosteric 2016). But, how do psychological defense mechanisms or evolutionary adaptability explain powerful and transformative experiences that lead individuals away from successful social positions of wealth and power, and towards political activism, a life of working the land, or selfless support of the poor? This is certainly a question that needs to be addressed, but space limitations and the need to emphasize the fact that "authentic" mystical experience sometimes seems to drive an action-oriented "turn to the left" requires us to put this aside for now. Here, we will simply state that people who have a mystical experience sometimes ${ }^{6}$ turn to the left and take up action.

This is a moderate position and should not be controversial, even for sociologists. Others go further and note a radical, even revolutionary, tone to most authentic mystical teachings. For example, of the Sermon on the Mount (Mathew 5), Happold (1963: 102) writes

The Sermon on the Mount is neither impractical idealism, nor a collection of unlivable moral precepts. It is a superb analysis of right action in the light of things as they really are and not as they appear to be. It is an expression of the mysticism of action.

Similarly, Harvey (1998) writes of connection with "the fire":

At the core of Christ's enterprise is an experience of this fire and the revolutionary passion of charity that blazes from it. This passion, as Christ knew it and lived it, cannot rest until it has burnt down all the divisions that separate one human heart from another and so from reality....no dogma, however hallowed, that keeps oppression of any kind alive can withstand the onslaught of its flame. All of human experience, personal and political, is arraigned and exposed by it. It demands of everyone who approaches it a loving and humble submission to its fierce, mind and heart shattering power and a commitment to enact it laws of radical compassion and hunger for

\footnotetext{
${ }^{5}$ If you are interested in Las Casas first-hand account and condemnation, you can read the book. It is available from Project Gutenberg at http://www.gutenberg.org/ebooks/20321.

${ }^{6} \mathrm{How}$ often this happens, and under what conditions, is a fascinating research questions for sociologists, I think.
} 
justice in every arena. Its aim is the irradiation of all life with holy and vibrant energy and truth so that as many beings as possible can live here on earth and in the body in a direct relationship with God, each other, and nature, in what Saint Paul unforgettably calls "the glorious liberty of the Children of God."

A relatively unknown, but nevertheless important medieval mystic by the name of Richard of St. Victor wrote action into the very substance of the mystic's experience and life. He noted that there were four degrees of ascending spirituality of connection with God. Notably, the last degree, the one that follows all others, is a return to the ground of Earth and progressive action in the name of God.

"In the first degree, God enters into the soul and she [sic] turns inward into herself. In the second, she ascends above herself and is lifted up to God. In the third, the soul, lifted up to God, passes over altogether into Him [sic]. In the fourth, the soul goes forth on God's behalf and descends below herself." Richard of St. Victor quoted in Harvey (1998).

After the descent back into "normal consciousness," the soul takes up an active life of social change in the body.

\section{Sanitation and Containment}

At this point we are in a bit of a quandary. If mystical experience leads us to "turn left," if authentic connection with God means we are suddenly more interested in progressive political and economic action, and even social justice, if the highest connection to God means grounded action in the world, the question must become, why did Karl Marx dismiss religion as mere opiate, why did Weber not develop his theoretic, and why have other sociologists and scientists not picked up on this with more force? The answer to that is simply because powerful people have worked against our realization of this important aspect of spiritual experience. We have been kept away from it, and for good reason. If authentic mystical experience has profound political and economic implications, these implications would not be welcome by the elites of any culture, in any epoch. The Powers That Be (PTB), whomever they happen to be in any particular epoch, would not be sympathetic to authentic mystical experience, nor would it be something in which they would want to encourage interest and inquiry into. It is not unreasonable to suggest that too many people having too many authentic mystical connections would lead to too great of pressure to transform the world. It is a reasonable concern, especially since it is possible to produce mystical experience consistently, efficiently, and in a manner neurologically identical to more traditional approaches like meditation (Sosteric 2016), through entheogen based interventions (Ellens 2014). In this context it is certainly reasonable to hypothesize that the $\mathrm{PTB}$, recognizing the revolutionary social and political potential inherent in mystical experience, engage in active suppression. This is exactly what Harvey suggests. As Harvey 
notes of the Christian church:

Many forces, even within the "Christian" world, block the unleashing of this "glorious liberty." Anyone who comes to feel even a small spark of the heat of this fire may look in vain to find any of its truth in the churches that claim to keep it alive. Fundamentalism of any kind is a misconception to its adoration of freedom and its all-embracing love of all beings and all creation; the narrow judgmental ethics that disfigure all denominations of Christianity represent precisely that separation that Christ himself wanted to end forever. Most Western seekers are refugees from hypocritical, patriarchal, misogynistic, and homophobic versions of Christ's message that are tantamount to perverse, even demonic betrayals of it. The great mystical treasures of all the Christian traditions have been largely ignored for centuries, even in the monastic institutions that might have kept them alive (Harvey 1998).

Harvey argues that Church and Christianity have ignored, even suppressed, the "great mystical treasures." Jantzen (1995) agrees, and suggest that initially the Church, and later academics, contained the revolutionary implications of mystical connection first within the confines of the structures and restrictions of the Church, and later within the canonical boundaries of sanitized academic conceptualizations and discourse.

In the case of the Church, the containment involves restricting access to the revolutionary teachings and revising and restricting concepts in order to tame down their transformative implications. The Church certainly did this from the very start. The Catholic Church is founded upon the selection of a small subset of available gospels, acts, and epistles. Elite members of the Church, headed up by the powerful bishop of Alexandria, stamped the canonical gospels at the Synod of Hippo (Ehrman 2007). They subsequently destroyed other available texts (Bock 2006), continued to edit and revise remaining texts down through the centuries (Ehrman 2007, 2003), and restricted mass access to the revolutionary teachings for over a thousand years (Starr 2013, Ehrman 2007). They even went so far as to burn those who tried to put the bible into the hands of the people. Starr (2013: 162) summarizes

Throughout the Middle Ages the Church went to great extremes to keep the Bible out of the hands of common people. Typical of prohibitions issues by the Church is the edict from the Council of Tarragona in 1234 that 'ordered all vernacular versions to be brought to the Bishop to be burned.' The 1408 Constitution of Oxford, England, strictly forbade the translation of the Bible in the native tongue. These restrictions were in line with a long tradition in Christianity of banning translations in native languages that extended into the sixteenth century and beyond. The ban on translations effectively took the Bible away from the populace, since few, if any commoners, could read Latin.

In my view, the Church did this because they were afraid of the transformative 
potential of the teachings, a fear that can be traced back to the very birth of the Messianic Christ who prophesied coming frightened the PTB so much that, according to the Gospel of Mathew, they ordered the mass murder of all newborn males at news that the Messiah had been born (Starr 2013: 185). If that horrendously violent act doesn't betray morbid fear of the liberating and transformative impact of mystical teachings, nothing does. There is certainly evidence in the bible to support a revolutionary view of Christ and mystical teachings. A careful reading of the New Testament shows a figure far different than the passive "Shepard of sheep" that Christian's priests so often depict. Christ was a revolutionary figure totally against slavery, sexism, commercialism, incarceration, and oppression of any kind (Sosteric 2017a). He totally ignored authority and tradition, refused to bow down before the local elites, and got himself assassinated as a result. Christ was disruptive of the status quo. One can understand why Roman emperors, Medieval Kings, and others would want to hide the gospels from the masses and/or spin interpretation of these gospels away from mystical experience (Sosteric n.d.).

As noted, containment of the mystical teachings can involve physically restricting access to texts, doctrinal restrictions, and even torturing and burning; but, it can also involve more academic approaches. For example, in order to contain mysticism conceptually, mystical experience may defined in a way that excludes from the category of mystic "any who are threatening to... authority" (Jantzen 1995: 14). This "sanitation" goes all the way back to Pythagoras (privileged member of the Greek slave society) and involves redefining mystical experience as an overly intellectualized, rational, "male" experience [an experience epitomized and idolized by the "pure conscious event" of Forman (1986)]. This definition excludes the oppressed and (notably) female experience from consideration (Jantzen 1995). Similarly, texts (if they cannot be destroyed) may be split into an exoteric or literal meaning, and an esoteric or hidden meaning. The hidden meaning then becomes accessible only to the "chosen" few, i.e. those who enter into elite monasteries, academies, and privileged private lodges. In this way, the disempowered and disenfranchised are excluded from learning about, talking about, and encouraging mystical experience, an experience that, as I would argue, may lead them to become "problems" for the ruling elites. Finally, there is a process of misdirection, whereby the attention of mystics and potential mystics is refocused on mystically vacuous institutional study and impotent ritual and sacrament rather than authentic mystical experience (Jantzen 1995) - the "parochial concentration on ecclesiastic institutions" already noted. Thus, instead of seeking out authentic mystical experience, we are led to kneel in pews and "drink the blood" of Christ. Finally Bender (2010) and Jantzen point out how the white, male definition of mystical experience as a privatized, ineffable, superconscious, highly personalized psychological experience has sanitized its revolutionary potential and turned mystical experience into a modern, mystical anesthetic. As Jantzen (1995: 346) notes:

The privatized, subjective ineffable mysticism of William James and his followers is open to women as well as to men, but it plays directly into the 
hands of modern bourgeois political and gender assumptions. It keeps God (and women) safely out of politics and the public realm, it allows mysticism to flourish as a secret inner life while those who nurture such an inner life can generally be counted on to prop up rather than to challenge the status quo of their workplaces, their gender roles, and the political systems by which they are governed since their anxieties and angers will be allayed in the privacy of their own hearts' search for peace and tranquility.

Certainly, my own work in this area supports this sanitation and containment hypothesis. The western Tarot deck, which some take to be a magical mystical tool of spiritual transformation, is really nothing more than an ideological prop for capitalist ideology and capitalist social relations. As I demonstrate, the Freemasons took a relatively innocuous pictorial Tarot deck, wrote elite ideology onto the deck, and subsequently turned it into an ideological weapon of mass indoctrination (Sosteric 2014). Put another way, Freemasons, in essence, created a tool that shapes and contains mystical experience, turns it away from its revolutionary roots, and puts it in a form more comfortable for the status quo.

Other examples of containment can be found. The new age movement itself may be viewed as an attempt to contain mysticism from the start. The New age movement originated in the "theosophical" work of Madame Blavatsky (Lachman 2012), ${ }^{7}$ who was herself a member of the Russian nobility. Her work has all the hallmarks of an attempt to contain and misdirect. Her work is difficult to get through (obfuscation, distraction), is based on fabricated sources (just like the Freemasons work with Tarot), and doesn't lead to direct mystical experience. Instead, it leads to reactionary politics and even racist expression. Indeed, her major works can be read as reactionary, proto-Nazi conceptualizations of race and privilege, which did indeed have influence on Nazi ideology (Goodrick-Clarke 1993, Kurlander 2012). And the containment goes on. Recent examples include The Secret and the Law of Attraction, which is a New Age philosophy that blames poverty on the individual, specifically their own "unconscious" blockages and "failure" to attract wealth, rather than the more economically and sociologically reasonable suggestion that it is the activities of elites which are causing the problems (Sharp 2016). A remarkable expression of containment leading to reactionary politics is the striking display of mystical naiveté by Shirley MacLaine, an aging actress and longtime pundit of New Age spirituality, who recently claimed that Jews might actually have deserved the holocaust because of "sins" in their past lives (Langley 2015). From the Catholic Church through Madam Blavatsky all the way to Shirley MacLaine and corporate spirituality (Carrette and King 2008), we have been led a long, long way from the transformative paths of this world's authentic mystics.

In closing I would like to note that Jantzen sees the sanitation/containment process as a violation of experience. While she vacillates on admitting there

\footnotetext{
${ }^{7}$ Lachman actually makes the hyperbolic claim that "practically all modern occultism and esotericism emerged from the ample bosom of ...HPB." As a representative of the political interests of the elites, she was definitely influential/ But as I and other have demonstrated, elite interference in the mystical teachings of this planet originates in historical epochs far removed from her.
} 
may be an authentic mystical core, she does say that "...the preoccupation of modern philosophers with the alleged intense psychological states of consciousness is a serious distortion of what the mystics themselves desired or held important" (Jantzen 1995: 7). That is certainly true. Speaking from my own personal mystical experiences, ${ }^{8}$ a careful reading of mystical texts, and an open assessment of the work of people like Bucke and Edward Carpenter (to name only two), it is very clear that mystics themselves are less concerned with the sterile conceptualizations and violating abstractions of church and academia and more concerned with truth, justice, and liberation of the species. It is the transformative, liberatory potential of mystical experiences (and the mystical teachers who exhort people to have mystical experiences of their own) which has motivated the sterilization and containment of mystical experience down through the centuries, in both Church and science.

\section{Conclusion}

The goal of this paper has not been to convince anybody of the nature or authenticity of mystical experience. You can believe it is a connection with God, a biological process rooted in evolutionary or psychological imperatives, a symbolic expression of our collective humanity, or whatever. For the purposes of this paper, the actual nature of mystical experience is irrelevant. The point here is to simply pique the readers' interest and point out that there is more going on than meets the proverbial eye. Hopefully I have done that. In a world of polemical and misinformed rejections of spirituality where scholars simply discard, reduce, and/or marginalize, we, and by "we" I mean people who are interested in open scientific inquiry of spiritual phenomenon, or we who are concerned about the social, economic, and environmental train wreck just around the corner, need to take a step back and take a second look. We need to question our knee jerk rejection of spirituality and "...refocus on the concerns vital to the mystics themselves, which have been suppressed. Not the least of these concerns is for political and social justice, including gender justice" (Jantzen 1995: 22), and global revolution. There is something important going on in the realm of mystical experience and it is important that we not let the sanitizers have control of the inquiry.

Whatever is going on in the realm of mystical experience, it is important we look. Whatever it is may be the missing piece to a puzzle that many scholars do not even know exists. This piece may explain why secularism has failed and

\footnotetext{
${ }^{8}$ I have to admit at this point that I am a professional sociologist and a professional mystic. Over a decade ago a series of powerful mystical experiences "broke open my head" and caused me to question what I would now view as the naïve materialism of modern science. I'm still working to understand, conceptualize, and provide an adequate and acceptable theorization of my experiences that honors both the realities of mystical experience, and the critical orientations and perspectives of science in general, and sociology in particular. This paper, which underlines and emphasizes the transformative potential of mystical experience, is a first stab in that direction. For more, see my paper entitled The Sociology of Mysticism Sosteric M. (2017b) The Sociology of Mysticism. ISA eSymposium for Sociology July.
} 
also why fundamentalist right wing alternatives have grown to such global power and force (Butler 2006). It may also help with a revitalization of the left. Butler (2006) notes that spirituality is a big deal for the vast majority of people on this planet. However, despite it being a big deal, the left has failed to properly understand, honor, and appreciate it. We all know why this is. Ever since Marx declared religion to be an opiate, we (and by "we" I mean the arrogant folks on the side of the left) have believed that we are "in possession of a truth superior to that of religion" (Bellah 1970: 91). As a result, we have not bothered to take a closer look and, perhaps worse, derisively dismiss those who bother to do so. But, this has been a mistake. Indeed, it is an abdication of responsibility. Our refusal to take this area seriously has played directly into the hands of social class elites who have engaged in a centuries long sanitization of mystical experience. The result is not only that we have left a power vacuum that the right has been able to move in and fill (Butler 2006), but also that we have consigned ourselves to a basic irrelevance to the people we seek to politicize and uplift. By ignoring mystical experience, we exclude a critical area of authentic human experience; by doing so we declare ourselves useless and redundant. Who is going to listen to us when we are so clearly clueless about something so important and pervasive as mystical and religious experience? The answer is nobody and the reactionary right knows it and exploits our dismissive arrogance (Butler 2006).

At this point, we can either continue in our soap box rejection or put aside our bias and take a closer look. I would argue that we have to step down off our soap box and take a closer look at spirituality and religious experience, with a view specifically towards properly theorizing it and (for those in the critical camps) with a view towards developing a critical/Marxist spirituality. We need to do this not only because, as (Lundskow 2005) notes, Marxism and critical theory face extinction by irrelevance, but also because the world needs a revolution, and badly. As Canty (2014) notes, the world faces a dramatic unraveling of the human and planetary systems. A recent editorial in the Monthly Review acknowledges the major global crises and calls for fundamental revolutionary change.

Indeed, so great is the epochal crisis of our time; encompassing both the economic and ecological crises, that nothing but a world revolution is likely to save humanity (and countless others among the earths' species) from a worsening series of catastrophes (Editorial 2014).

The editors go on say that "Real revolutionary transformations will emerge most readily today, as has been the case for more than a century, out of struggles in the periphery of the capitalist system where the material conditions that people must confront are more severe due to centuries of imperialist exploitation compounded now by the fact that climate change is hitting the global South the hardest." I would argue that this is not the case. While the periphery may rise up, the technology and violent capability of the center can easily put down any uprising that may occur. What is actually needed is a global transformation at 
the center, and the periphery. And by this I do not mean at the center of imperialist power so much as I do the center of the human heart. What is needed is a technology of interpersonal transformation, a technology of spiritual transformation, that is systematic, professional, and that self-consciously addresses the question raised by this paper, can authentic mystical experiences induce progressive change within the heart and mind of the individual. If a single mystical experience is enough to transform a violent colonizer like Las Casas, what might a properly developed and conceptualized, progressive and scientifically grounded, technology of mystical experience and exploration be able to accomplish? Is it unreasonable to suggest that poor and rich may be transformed in the process? Las Casas was rich and he was transformed, and others were as well. And if the reader continues to resist I simply ask, "how do you know?" Most academics have not taken the mystical core seriously, and many who have, have participated in its sanitation; so, how do you know what is possible here? It is reasonable to suggest that there is something here worth looking at? As Harvey notes

There is nothing more important... for the future of the planet - than an authentic and unsparing recovery of the full range, power, and glory of the Christian mystical tradition. Without such a recovery, the spiritual life of the West will continue to be a superficial, narcissistic, and sometimes lethal mixture of a watered-down or fanatical pseudo-Christianity; hardly understood "Eastern" metaphysics and regressive occultism — and the great radical potential of such a renaissance will go unlived and unenacted with disastrous consequences for every human being and for all of nature.

While I would disagree with Harvey only on the stipulation that we need to recover "Christian mystical tradition" (there are lots of mystical traditions in the East and West), I would agree that mystical experience is critical. Is it not hyperbole to suggest that it is authentic mystical experience, a "cosmic religion" as Einstein suggested (Hermanns 1983, Martin and Ott 2013) that may make the difference between a violent descent into political and environmental chaos, and the transformation of the world? Whether one agrees with this statement or not, we certainly need to take a closer look. We, and by "we" I mean the "progressive" left, have been too busy holding our noses and turning our heads to adequately assess. To be sure, it may be true that a closer examination of mystical experience reveals that there is a rotten core, but I do not think so. It has long been known that authentic mystical experience is a scaffold for psychological and mental health and healing. I think that authentic mystical experience is also a scaffold for global transformation and as such, sociologists and others have to quit dismissing it and start taking it as deserving of serious scholarly attention. 


\section{References}

Alighieri D (1915) The Divine Comedy. New Haven: Yale University Press. Anon (2009) Edward Carpenter: Red, Green and Gay. Socialism Today 131.

Anthony F-V, Hermans CAM, Sterkens C (2010) A Comparative Study of Mystical Experience Among Christian, Muslim, and Hindu Students in Tamil Nadu, India. Journal for the Scientific Study of Religion 49: 264-277.

Bellah RN (1970) Christianity and Symbolic Realism. Journal for the Scientific Study of Religion 9: 89-96.

Bender C (2010) The New Metaphysicals: Spirituality and the American Religious Imagination, Chicago: University of Chicago Press.

Berger P (1968) A Bleak Outlook is Seen for Religion: The New York Times.

Berger P (1969) The Sacred Canopy: Elements of a Sociological Theory of Religion. New York: Anchor Books.

Berger P (1997) Epistemological Modesty: An Interview with Beter Berger. The Christian Century 114: 972-975, 978.

Berger P (1999) The Descularization of the World: Resurgent Religion and World Politics. Grand Rapids MI: Eerdmans.

Blake W (1906a) Letter to Thomas Butts. In AGB Russell (ed) The Letters of William Blake together with His Life, 117-124. New York: Charles Scribner's Sons.

Blake W (1906b) To Mr. Butts. In AGB Russell (ed) The Letters of William Blake together with His Life, 124-130. New York: Charles Scribners' Sons.

Blake W (1906c) To Thomas Butts. In AGB Russell (ed) The Letters of William Blake together with His Life, 113-116. New York: Charles Scribner's Sons.

Blake W. (1906d) To Thomas Butts. In AGB Russell (ed) The Letters of William Blake, 96-102. New York: Charles Scribner's Sons.

Blake W (1906e) To Thomas Butts. In AGB Russell (ed) The Letters of William Blake, 90-93. New York: Charles Scribner's Sons.

Bock DL (2006) The Missing Gospels: Unearthing the Truth Behind Alternative Christianities. Nashville, Tennessee: Thomas Nelson.

Bourque LB (1969) Social Correlates of Transcendental Experiences. Sociological Analysis 30: 151-163.

Bourque LB, Back KW (1971) Language, Society and Subjective Experience. Sociometry 34: 1-21.

Bruce S (2002) God is Dead: Secularization in the West. Oxford: Blackwell.

Bucke RM (2009/1929) Cosmic Consciousness. New York: E.P. Dutton.

Butler J (2006) Born Again: The Christian Right Globalized, New York: Pluto Press.

Canty JM (2014) Walking Between Worlds: Holding Multiple Worldviews as a Key for Ecological Transformation. The International Journal of Transpersonal Studies 33: 15-26.

Carpenter E (1889) Civilization: Its Cause and Cure And Other Essays. New York: Charles Scribner's Sons.

Carpenter E (1896) Towards Democracy. New York: Labour Press.

Carpenter E (1921) The Art of Creation: Essays on the Self and Its Powers. London: Georbe Allen \& Unwin.

Carrette J, King R (2008) Selling Spirituality: The Silent Takeover of Religion. New York: Routledge.

Cels M (2014) Personal email. 
Chen Z, Qi W, Hood RW, et al. (2011) Common Core Thesis and Qualitative and Quantitative Analysis of Mysticism in Chinese Buddhist Monks and Nuns. Journal for the Scientific Study of Religion 50: 654-670.

Cohn SF, Markides KC (2013) Religion and spiritual experience: Revisiting key assumptions in sociology. International Journal of Transpersonal Studies 32(2): 34 41.

Dawkins R (2006a) The God Delusion. New York: Mariner Books.

Dawkins R (2006b) Religion's Real Child Abuse. Retrieved from http://bit.ly/2Bw 2hLx.

Dobbelaere K (1981) Trend Report: Secularization: A Multi-Dimensional Concept. Current Sociology 29: 3-153.

Dobbelaere K (2002) Secularization: An Analysis at Three Levels. Frankfurt: Peter Lang.

Durkheim E (1965) The Elementary Forms of Religious Life. New York: Free Press.

Ecklund EH (2012) What Scientists Really Think, Oxford: Oxford University Press.

Ecklund EH, Long E (2011) Scientists and Spirituality. Sociology of Religion 72: 253-274.

Editorial (2014) Notes from the Editors. The Monthly Review 66.

Ehrman BD (2003) Lost Scriptures. New York: Oxford University Press.

Ehrman BD (2007) Misquoting Jesus: The Story Behind Who Changed the Bible and Why: Harper One.

Ellens JH (2001) The Destructive Power of Religion: Violence in Judaism, Christianity, and Islam. Westport, CT: Praegar.

Ellens JH (2014) Seeking the Sacred with Psychoactive Substances: Chemical Paths to Spirituality and to God. California: Praeger.

Ellis A (1988) Is religiosity pathological. Free Inquiry 18.

Ellis A (2000) Spiritual goals and spirited values in psychotherapy. Journal of Health and Social Behaviour 32.

Featherstone R, Sorrell K (2007) Sociology Dismissing Religion? The Presentation of Religious Change in Introductory Sociology Textbooks. American Sociologist 38: $78-98$.

Fiske J (1902) The Historical Writings of John Fiske: The Discovery of America, New York: Houghton Mifflin.

Forman RKC (1986) Pure consciousness events and mysticism. Sophia 25: 49-58.

Freeman A (2005) The Sense of Being Glared At: What is it Llke to be a Heretic? Journal of Consciousness Studies 12: 4-9.

Freud S (1961) Civilization and its Discontents. New York: W.W. Norton.

Freud S (1964) The Future of an Illusion. New York: Anchor Books.

Garrett WR (1975) Maligned mysticism: the maledicted career of Troeltsch's third type. SA. Sociological Analysis 36: 205-223.

Goodrick-Clarke N (1993) The Occult Roots of Nazism: Secret Aryan Cults and Their Influence on Nazi Ideology. New York: NYU Press.

Greeley A (1975) The Sociology of the Paranormal: A Reconnaissance. Beverly Hills, CA: Sage Publications.

Grof S, Grof C. (1989) Spiritual Emergency: When Personal Transformation Becomes a Crises. New York: Putnam.

Happold FC (1963) Mysticism: A Study and Anthology. New York: Penguin Books.

Harvey A (1998) Teachings of the Christian Mystics. Boston: Shambhala Publications.

Hermanns W (1983) Einstein and the Poet. Boston: Branden Books.

Hood Jr RW, Hill PC, Spilka B (2009) The Psychology of Religion, Fourth Edition: An Empirical Approach. London: The Guilford Press.

Hood RW, Ghorbani N,Watson PJ (2001) Dimensions of the mysticism scale: confirming the three-factor structure in the United States and Iran. Journal for the Scientific Study of Religion 40: 691-705. 
Inge RWR (2005) Mysticism in Religion. New York: Hutchinson's University Library.

James W (1982) The Varieties of Religious Experience: A Study of Human Nature. New York: Penguin.

Jantzen GM (1995) Power, Gender, and Christian Mysticism. New York: Cambridge University Press.

Kurlander E (2012) Hitler's Monsters: The Occult Roots of Nazism and the Emergence of the Nazi ‘Supernatural Imaginary'. German History 30: 528-549.

Lachman G (2012) Madame Blavatsky: The Mother of Modern Spirituality. New York: Penguin.

Langley W (2015) Shirley MacLaine: Misguided or Mad as a Hatter? The Telegraph. UK: Telegraph Media Group.

Lazar A, Kravetz S (2005) RESEARCH:"Responses to the Mystical Scale by Religious Jewish Persons:A Comparison of Structural Models of Mystical Experience". International Journal for the Psychology of Religion 15: 51-61.

Lundskow G (2005) Marxist Class-Cultural Spirituality in Theory and Practice. Critical Sociology 21: 213-241.

Martin W, Ott M (2013) The Cosmic View of Albert Einstein: Writings on Art, Science, and Peace. Sterling Ethos.

Maslow AH (1943) A Theory of Human Motivation. Psychological Review 50: 370-396.

Maslow AH (1959a) Cognition of being in the peak experiences. The Journal of Genetic Psychology 94: 43.

Maslow AH (1959b) Critique of Self-Actualization. I. Some Dangers of Being-Cognition. Journal of Individual Psychology 15: 24.

Maslow AH (1964) Religions, Values, and Peak Experiences. Columbus: Ohio State University Press.

Maslow AH (1968) Towards a Psychology of Being ( $2^{\text {nd }}$ ed). New York: Van Nostrand Reinhold Company.

Maslow AH (1969) The farther reaches of human nature. Journal of Transpersonal Psychology 1: 1-9.

Maslow AH (1971) The Farther Reaches of Human Nature. New York: Viking.

Maslow AH (1994) Religions, Values, and Peak-Experiences. New York: Penguin.

Maslow AH (2012) The "Core-Religious" or "Transcendent" Experience. In J White (ed) The Highest State of Consciousness, 339-350. New York: Doubleday.

Masterman CFG (1907) Leaders of the Church: Frederick Denison Maurice. London: Oxford.

Miller WR (2004) The phenomenon of quantum change. Journal of Clinical Psychology: 453.

Morena J (2000) Undue Risk: Secret State Experiments on Humans. New York: Routledge.

Müller MF (1881) Buddhist Suttas. Oxford: Clarendon Press.

Newberg A, d'Aquile E, Rause V (2001) Why God Won't Go Away: Brain Science and the Biology of Belief. New York: Ballantine Books.

Parmar H (2002) Paradise Lost and the Divine Comedy: A Comparative Study. New Delhi: Sarup \& Sons.

Proudfoot W (1985) Religious Experience. California: University of California Press.

Roberts TB (2014) From the 500--Year Blizzard of Words to Personal Sacred Experiences--The New Religious Era. In JH Ellens (ed) Seeking the Sacred with Psychoactive Substances: Chemical Paths to Spirituality and to God, 1-22. California: Praeger.

Robertson R (1975) On the analysis of mysticism : pre-Weberian, Weberian and postWeberian perspectives. SA. Sociological Analysis 36: 241-266.

Rowbotham S (1980) In Search of Edward Carpenter. Radical America 14. 
Rowbotham S (2008) Edward Carpenter: A Life of Liberty and Love. New York: Verso.

Sharp M (2006) The Book of Light: The Nature of God, the Structure of Consciousness, and the Universe Within You. St. Albert, Alberta: Lightning Path Press.

Sharp M (2010) The Rocket Scientists' Guide to Authentic Spirituality. St. Albert, Alberta: Lightning Path Press.

Sharp M (2016) The Rocket Scientists' Guide to Money and the Economy: Accumulation and Debt. St Albert, Alberta: Lightning Path Press.

Sime AHM (1916) Edward Carpenter: His Ideas and Ideals. London: E.P Dutton \& Co.

Sosteric M (2014) A Sociology of Tarot. Canadian Journal of Sociology 39.

Sosteric M (2016) A Neurologically Grounded Theory of Mystical/Spiritual Experience. Retrieved from http://bit.ly/2BuAHhy.

Sosteric M (2017a) Rock and Roll Jesus Part One: Anti-authoritarian, political emancipator, and revolutionary liberator.

Sosteric M (2017b) The Sociology of Mysticism. ISA eSymposium for Sociology July.

Sosteric M (n.d.) Rock and Roll Jesus Part Two: A Martyr/Star is Born [unpublished].

Stace WT (1960a) Mysticism and Philosophy. London: Macmillan.

Stace WT (1960b) The Teachings of the Mystics. New York: Mentor.

Starr B (2013) Jesus Uncensored: Restoring the Authentic Jew: OmniHouse Publishing.

Summers-Effler E, Kwak HD (2015) Weber's missing mystics: inner-worldly mystical practices and the micro potential for social change. Theory and Society 44: 251-282.

Tiryakian EA (1972) Toward the Sociology of Esoteric Culture. American Journal of Sociology 78: 491-512.

Truzzi M (1974) Definitions and dimensions of the occult: Towards a sociological perspective. In A Tiryakian (ed) On the margin of the visible: Sociology, the esoteric and the occult, 243-257. New York: Wiley.

Underhill E (2002) Mysticism: A Study in the Nature and Development of Spiritual Consciousness. New York: Dover Publications.

Vergote A (2003) Plying Between Psychology and Mysticism. In JA Belzen, A Geels (eds) Mysticism: A Variety of Psychological Perspectives,81-107. New York: Rodopi.

Washington H (2008) Medical Apartheid: The Dark History of Medical Experimentation on Black Americans from Colonial Times to the Present. New York: Anchor.

Whitman W (2007) Leaves of Grass: The Original 1855 Edition. New York: Dover.

Wilber K (2001) Quantum Questions: Mystical Writings of the World's Great Physicists New York: Shambhala. 
